\title{
MODEL BANGKITAN PERJALANAN PADA KAWASAN PINGGIRAN MENUJU PUSAT KOTA (STUDI PADA KAWASAN YANG MENGALAMI PERUBAHAN SPASIAL)
}

\author{
Theresia A. Bria ${ }^{1}$, Tedy Wonlele ${ }^{2}$, Onisius Loden ${ }^{3}$ \\ ${ }^{1}$ Jurusan Teknik Sipil, Politeknik Negeri Kupang \\ Email:briathessa2909@gmail.com \\ ${ }^{2}$ Jurusan Teknik Sipil, Politeknik Negeri Kupang \\ Email:twonlele@gmail.com \\ ${ }^{3}$ Jurusan Teknik Sipil, Politeknik Negeri Kupang \\ Email:oniloden_2008@yahoo.co.id
}

\begin{abstract}
ABSTRAK
Pertumbuhan dan perkembangan kota-kota di Indonesia sangat berpengaruh pada perubahan spasial wilayah-wilayah di sekitarnya. Kawasan pinggiran yang awalnya adalah desa, kini berubah secara fisik menjadi kawasan kota baru yang ditandai dengan berkurangnya penggunaan lahan untuk pertanian di satu sisi penggunaan lahan untuk pemukiman dan kegiatan ekonomi semakin meningkat. Namun demikian, ketergantungan terhadap kota induknya sangat besar terutama untuk kegiatan pendidikan, bekerja dan memenuhi kebutuhan sehari-hari. Hal inilah yang kemudian menjadi salah satu penyebab terjadinya pergerakan. Oleh karena itu sangat penting untuk mengetahui bagaimana model bangkitan perjalanan dari kawasan pinggiran menuju kawasan perkotaan. Studi ini mengambil lokasi di wilayah Kota Kupang dengan wilayah pinggiran terdiri dari kawasan Penfui Timur dan sekitarnya. Model yang dikembangkan adalah menggunakan analisa regresi linier. Hasil menunjukkan bahwa variabel yang berpengaruh terhadap bangkitan perjalanan adalah jumlah anggota keluarga dengan koefisen regresi (0.2832), jumlah anggota keluarga yang bersekolah $(0.3763)$ dan pendapatan $\left(1.8^{*} 10^{-7}\right)$ serta nilai konstanta sebesar 1.4062. Berdasarkan hasil ini, maka untuk mengurangi perjalanan ke kota salah satu upaya yang perlu dilakukan adalah dengan memperluas akses untuk mendapatkan pendidikan di sekitar kawasan pinggiran sehingga perjalanan dengan tujuan sekolah ke kota dapat dikurangi.
\end{abstract}

\section{Kata Kunci : Bangkitan, Perjalanan, Kawasan, Pinggiran}

\section{PENDAHULUAN}

Pada banyak kota sedang berkembang di Indonesia, kecenderungan terjadinya perubahan spasial pada daerahdaerah pinggiran kota merupakan fenomena yang sering terjadi. Hal ini menyebabkan terjadinya perubahan kawasan yang tadinya merupakan desa atau kampung di pinggiran, menjadi kota-kota kecil yang sering disebut sebagai desakota. Fenomena ini dipicu oleh adanya tata guna lahan yang umumnya secara tegas memisahkan antara pemukiman dan pusat bisnis atau pusat kegiatan ekonomi ditambah lagi dengan mahalnya akses untuk mendapatkan perumahan di kota sehingga kawasan pinggiran menjadi alternatif sebagai tempat tinggal. Salah satu indikator yang dapat mengukur adanya perubahan spasial ini dilihat dari terjadinya perubahan dalam struktur mata pencaharian pada sektor non pertanian yang meningkat serta di satu sisi terjadi penurunan luas lahan pertanian di desa [1]. Meski kawasan ini mengalami pertumbuhan akan tetapi tetap sangat bergantung pada kota induknya dalam berbagai sektor [2].

Hal inilah yang menyebabkan terjadinya perjalanan dari desa (kawasan pinggiran) menuju ke kota baik untuk tujuan bekerja, sekolah, berbelanja, wisata dan kegiatan sosial. Berkaitan dengan itu, kawasan desa adalah kawasan bangkitan sedangkan kota adalah tarikan perjalanan. Interaksi antara bangkitan dan tarikan ini, maka terjadilah pergerakan. Namun demikian, pergerakan ini terjadi tidak hanya kedua faktor tersebut di atas akan tetapi pergerakan yang terjadi sangat tergantung pada aksesibilitas dan mobilitas yang tersedia. Aksesibilitas dan mobilitas yang baik akan mendorong terjadinya pergerakan dan dapat mempercepat meningkatnya pertumbuhan suatu kawasan [3].

Secara teoritis, analisis terhadap bangkitan perjalanan merupakan bagian dari konsep perencanaan transportasi perkotaan. Dalam konsep perencanaan transportasi tradisional dikenal dengan konsep model empat tahap (four step model-FSM) yang terdiri dari trip generation (bangkitan perjalanan), trip distribution (distribusi perjalanan), mode choice (pemilihan moda) dan route choice (pemilihan rute) [4] [5] [6].

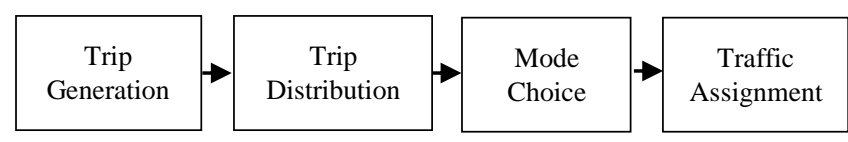

Gambar 1. Tahapan dalam model FSM 
Dari Gambar 1 terlihat bangkitan perjalanan adalah tahapan awal dalam model untuk memperkirakan jumlah harian perjalanan berbasis zona dan rumah tangga [5] [7]. Dari jumlah perjalanan harian ini kemudian dapat direncanakan distribusi perjalanan menggunakan moda tertentu pada rute tertentu. Melalui analisis dalam konsep perencanaan ini diharapkan dapat diperoleh suatu kondisi pergerakan yang efisien dan efektif. Namun demikian, FSM sebenarnya merupakan pendekatan tradisional yang dipakai untuk memperkirakan kebutuhan akan perjalanan yang dikritik memiliki kelemahan, tidak mampu menjelaskan perilaku perjalanan secara utuh. Untuk itu dipakailah pendekatan generasi baru dalam perencanaan pemodelan kebutuhan transportasi yaitu berdasarkan pada pendekatan aktivitas (activity based) [8]. Pendekatan aktivitas dalam pemodelan kebutuhan transportasi ini terdiri dari dua model yaitu pertama model tour based dimana setiap perjalanan berawal dan berakhir pada tempat yang sama (umumnya pada home based) sedangkan model kedua activity scheduling yaitu sebuah perjalanan berdasarkan aktivitas di luar rumah yang sudah terjadwal secara jelas dan dibutuhkan untuk mengakses kegiatan tersebut [9].

Untuk itu, perlu kiranya dipahami faktor-faktor apa saja yang dapat memengaruhi seseorang untuk melakukan perjalanan. Beberapa studi terdahulu, mencoba menjelaskan berbagai faktor yang dapat memengaruhi seseorang dalam melakukan perjalanan. Faktor-faktor yang sering menjadi dasar kajian dalam menganalisis bangkitan adalah pendapatan rumah tangga, kepemilikan kendaraan, jumlah anggota keluarga dalam satu rumah tangga, dan struktur dalam rumah tangga serta yang dianalisis menggunakan pendekatan berbasis aktivitas [7]. Studi lain yang dilakukan di Kota Jember mendapatkan fakta bahwa faktorfaktor yang mempengaruhi bangkitan perjalanan adalah pendapatan keluarga dalam satu bulan, jumlah anggota keluarga, jumlah anggota keluarga yang bekerja, dan jumlah anggota keluarga yang sekolah [10]. Sementara itu, di Palu, dalam analisis bangkitan terhadap salah satu kecamatan di Kota Palu diketahui bahwa faktor yang memengaruhi bangkitan perjalanan adalah jumlah anggota keluarga, kepemilikan kendaraan roda dua dan pendapatan [11].

Selanjutnya, penelitian lain tentang bangkitan perjalanan pada pusat kegiatan pemukiman dengan tujuan kawasan Telkom Jalan A.P Pettarani Makassar, dipengaruhi oleh kepemilikan mobil, jenis moda dan tujuan meninggalkan rumah, dan model yang paling berpengaruh terhadap pusat kegiatan (perumahan) adalah jenis moda yang digunakan [12].

Dari suatu studi di Bogota Columbia, menunjukkan hasil bahwa pendapatan, struktur dan ukuran rumah tangga, kepemilikan mobil, waktu perjalanan dan tata guna lahan berpengaruh pada bangkitan perjalanan. Hasil menunjukkan bahwa model trip attraction merupakan model terbaik untuk melakukan estimasi menggunakan data zona [13].
Dari beberapa studi di atas terlihat bahwa interaksi antara tata guna lahan, faktor rumah tangga dan sistem transportasi melahirkan perjalanan orang dari satu daerah asal ke suatu tujuan tertentu. Oleh karena itu, dalam artikel ini akan dibahas model bangkitan perjalanan dari kawasan pinggiran kota (suburban) sebagai daerah asal menuju ke kawasan kota (urban) sebagai daerah tujuan. Studi ini mengambil lokasi di Kota Kupang NTT, yang secara geografis berbatasan langsung dengan Kabupaten Kupang dimana terdapat beberapa desa yang berbatasan langsung dengan Kota Kupang yaitu kawasan Penfui Timur dan sekitarnya, Tarus dan Taebenu. Desa-desa ini kemudian dalam perkembangannya mengalami perubahan ruang seiring dengan waktu yang ditandai salah satunya dari perubahan fungsi lahan untuk pertanian dan peternakan menjadi kawasan permukiman, sekolah, pusat perbelanjaan dan lainnya.

\section{METODE}

Penelitian ini dimaksudkan untuk menghasilkan model bangkitan perjalanan dari daerah suburban yang mengalami perubahan spasial ke kawasan perkotaan. Untuk kawasan suburban yang diteliti adalah kawasan Penfui Timur dan sekitarnya yang berbatasan langsung dengan Kota Kupang. Survei menggunakan kuesioner yang diisi langsung maupun lewat media online. Jumlah kuesioner yang dapat dianalisis sebanyak 135 kuesioner (responden).

Model yang digunakan untuk meramalkan bangkitan perjalanan adalah model persamaan regresi linier berganda dengan variabel terikat adalah jumlah perjalanan per hari. Secara teoritis faktor -faktor yang dapat memengaruhi bangkitan perjalanan adalah faktor internal dan eksternal. Faktor internal antara lain adalah usia, pekerjaan, penghasilan, jumlah anggota keluarga, kepemilikan kendaraan, dan liannya. Sedangkan faktor eksternal adalah antara lain jarak dari rumah ke pusat kota, tempat kerja, fasilitas hiburan, sekolah dan lain sebagainya. Selain itu, faktor tata guna lahan juga memengaruhi pergerakan dalam suatu sistem. Atas dasar itu dalam penelitian ini variabel yang digunakan sebagai variabel bebas adalah sebagai berikut : $\left(\mathrm{X}_{1}\right)$ Kepemilikan rumah; $\left(\mathrm{X}_{2}\right)$ Jumlah anggota keluarga; $\left(\mathrm{X}_{3}\right)$ Jumlah anggota keluarga yang bekerja; $\left(\mathrm{X}_{4}\right)$ Jumlah anggota keluarga yang sekolah; $\left(\mathrm{X}_{5}\right)$ Pendapatan; $\left(\mathrm{X}_{6}\right)$ Kepemilikan Mobil; $\left(\mathrm{X}_{7}\right)$ Kepemilikan sepeda motor; $\left(\mathrm{X}_{8}\right)$ Kepemilikan SIM; $\left(\mathrm{X}_{9}\right)$ Jarak tempuh; $\left(\mathrm{X}_{10}\right)$ Waktu tempuh.

Berdasarkan variabel di atas dapat dibentuk persamaan regresi linier sebagai berikut :

$$
\begin{aligned}
& Y=C+\beta_{1} X_{1}+\beta_{2} X_{2}+\beta_{3} X_{3}+\beta_{4} X_{4}+\beta_{5} X_{6}+\cdots \ldots+ \\
& \beta_{10} X_{10}
\end{aligned}
$$

$$
\begin{aligned}
& \text { Dengan: } \\
& \begin{array}{ll}
\mathrm{Y} & =\text { jumlah perjalanan per hari setiap rumah tangga } \\
\mathrm{X}_{1-10} & =\text { peubah } / \text { variabel bebas } \\
\beta_{1-10} & =\text { koefisien regresi } \\
\mathrm{C} & =\text { konstanta }
\end{array}
\end{aligned}
$$


Selanjutnya, persamaan regresi yang dihasilkan akan diuji normalitas, uji heteroskedastisitas, uji multikolinearitas dan autokorelasi, uji F Regresi dan T Parsial. Selain itu, akan ditentukan juga nilai R Square dan Standart Error of Estimate (SEE) dari persamaan regresi yang menunjukkan semakin baiknya persamaan regresi yang dihasilkan.

\section{HASIL DAN PEMBAHASAN}

\subsection{Uji Korelasi}

Sebelum melakukan analisis regresi, maka terlebih dahulu dilakukan uji korelasi terhadap variabel independen $\left(\mathrm{X}_{1}-\right.$ $\mathrm{X}_{10}$ ) terhadap variabel terikat : jumlah perjalanan rumah tangga per hari (Y) dan korelasi antar variabel. Variabel yang akan digunakan dalam membuat persamaan regresi adalah variabel yang nilai korelasinya $>4,0$ yang menunjukkan tingkat hubungan dari sedang hingga sangat kuat berdasarkan pada Tabel 1. Korelasi ini penting karena menunjukkan tingkat hubungan antar variabel. Selanjutnya, menggunakan analisis korelasi akan dicari hubungan antara variabel terikat $\mathrm{Y}$ dan variabel bebas $\mathrm{X}$.

Tabel 1 Interval koefisien korelasi dan tingkat hubungan

\begin{tabular}{cc}
\hline Interval Koefisien & Tingkat Hubungan \\
\hline $0.00-0.199$ & Sangat Rendah \\
$0.20-0.399$ & Rendah \\
$0.40-0.599$ & Sedang \\
$0.60-0.799$ & Kuat \\
$0.80-1.00$ & Sangat Kuat \\
\hline & Sumber : [14]
\end{tabular}

Hasil analisis korelasi ditunjukkan dalam Tabel 2. Dari hasil ini diketahui bahwa variabel $\mathrm{X}_{2}$ (jumlah anggota keluarga), $X_{4}$ (jumlah anggota keluarga yang sekolah) dan $\mathrm{X}_{5}$ (pendapatan) merupakan variabel dengan korelasi yang kuat dengan jumlah perjalanan per hari (Y).

Tabel 2 Koefisien Korelasi antar variabel

\begin{tabular}{|c|c|c|c|c|c|c|c|c|c|c|}
\hline & $\mathrm{Y}$ & X1 & $\mathrm{X} 2$ & X3 & X4 & X5 & X6 & X7 & X8 & X9 \\
\hline $\mathrm{X} 1$ & $\begin{array}{r}-0.025 \\
0.770\end{array}$ & 1 & & & & & & & & \\
\hline $\mathrm{X} 2$ & $\begin{array}{l}0.752 \\
0.000\end{array}$ & $\begin{array}{c}-0.008 \\
0.923\end{array}$ & 1 & & & & & & & \\
\hline X3 & $\begin{array}{l}0.212 \\
0.014\end{array}$ & $\begin{array}{l}0.046 \\
0.600\end{array}$ & $\begin{array}{l}0.233 \\
0.006\end{array}$ & 1 & & & & & & \\
\hline $\mathrm{X} 4$ & $\begin{array}{l}0.752 \\
0.000\end{array}$ & $\begin{array}{l}0.075 \\
0.389\end{array}$ & $\begin{array}{l}0.779 \\
0.000\end{array}$ & $\begin{array}{c}-0.003 \\
0.972\end{array}$ & 1 & & & & & \\
\hline X5 & $\begin{array}{l}0.575 \\
0.000\end{array}$ & $\begin{array}{l}0.079 \\
0.359\end{array}$ & $\begin{array}{l}0.581 \\
0.000\end{array}$ & $\begin{array}{l}0.505 \\
0.000\end{array}$ & $\begin{array}{l}0.512 \\
0.000\end{array}$ & 1 & & & & \\
\hline X6 & $\begin{array}{l}0.249 \\
0.004\end{array}$ & $\begin{array}{l}0.147 \\
0.088\end{array}$ & $\begin{array}{l}0.298 \\
0.000\end{array}$ & $\begin{array}{l}0.068 \\
0.434\end{array}$ & $\begin{array}{l}0.329 \\
0.000\end{array}$ & $\begin{array}{l}0.355 \\
0.000\end{array}$ & 1 & & & \\
\hline $\mathrm{X} 7$ & $\begin{array}{l}0.157 \\
0.070\end{array}$ & $\begin{array}{l}0.187 \\
0.030\end{array}$ & $\begin{array}{l}0.112 \\
0.197\end{array}$ & $\begin{array}{l}0.101 \\
0.247\end{array}$ & $\begin{array}{l}0.160 \\
0.065\end{array}$ & $\begin{array}{l}0.071 \\
0.415\end{array}$ & $\begin{array}{l}0.031 \\
0.720\end{array}$ & 1 & & \\
\hline X8 & $\begin{array}{l}0.137 \\
0.113\end{array}$ & $\begin{array}{l}0.249 \\
0.004\end{array}$ & $\begin{array}{l}0.113 \\
0.192\end{array}$ & $\begin{array}{l}0.175 \\
0.042\end{array}$ & $\begin{array}{l}0.074 \\
0.392\end{array}$ & $\begin{array}{l}0.151 \\
0.081\end{array}$ & $\begin{array}{l}0.169 \\
0.051\end{array}$ & $\begin{array}{l}0.301 \\
0.000\end{array}$ & 1 & \\
\hline X9 & $\begin{array}{c}-0.138 \\
0.111\end{array}$ & $\begin{array}{c}-0.155 \\
0.073\end{array}$ & $\begin{array}{c}-0.098 \\
0.257\end{array}$ & $\begin{array}{c}-0.057 \\
0.509\end{array}$ & $\begin{array}{c}-0.147 \\
0.089\end{array}$ & $\begin{array}{c}-0.120 \\
0.167\end{array}$ & $\begin{array}{c}-0.159 \\
0.066\end{array}$ & $\begin{array}{c}-0.038 \\
0.665\end{array}$ & $\begin{array}{c}-0.043 \\
0.621\end{array}$ & 1 \\
\hline X10 & $\begin{array}{l}-0.107 \\
0.219\end{array}$ & $\begin{array}{l}0.122 \\
0.158\end{array}$ & $\begin{array}{c}-0.160 \\
0.063\end{array}$ & $\begin{array}{l}0.130 \\
0.132\end{array}$ & $\begin{array}{c}-0.171 \\
0.049\end{array}$ & $\begin{array}{c}-0.045 \\
0.606\end{array}$ & $\begin{array}{c}-0.271 \\
0.001\end{array}$ & $\begin{array}{l}0.297 \\
0.000\end{array}$ & $\begin{array}{l}0.216 \\
0.012\end{array}$ & $\begin{array}{l}0.502 \\
0.000\end{array}$ \\
\hline
\end{tabular}

Dari analisis korelasi di atas juga terlihat bahwa variabel bebas yang dipilih, ternyata semua variabel memiliki korelasi antar variabel yang kuat. Korelasi antara variabel $\mathrm{X}_{2}$ dan $\mathrm{X}_{4}$ dimana korelasinya 0.779 dan variabel $\mathrm{X}_{2}$ dan $\mathrm{X}_{5}$ memiliki korelasi sebesar 0.581 sedangkan $\mathrm{X}_{4}$ dan $\mathrm{X}_{5}$ memiliki korelasi sebesar 0.512. Oleh karena itu, maka pembentukan persamaan regresi dapat dilakukan secara bersama-sama untuk semua variabel di atas, sehingga persamaan yang dapat dibentuk sebagai berikut :

$$
Y=C+\beta_{2} X_{2}+\beta_{4} X_{4}+\beta_{5} X_{5}
$$

\subsection{Hasil Analisis}

Berdasarkan hasil analisa korelasi di atas telah diperoleh tiga variabel yang memiliki hubungan yang kuat dengan variabel $\mathrm{Y}$, yaitu $\mathrm{X}_{2}, \mathrm{X}_{4}, \mathrm{X}_{5}$. Dari ketiga variabel tersebut kemudian dianalisis untuk mendapatkan suatu model persamaan regresi. Hasil analisis ditunjukkan pada Tabel 3. 
Tabel 3 Hasil analisa model regresi linier

\begin{tabular}{|c|c|c|c|c|c|}
\hline Predictor & Coef & $\begin{array}{c}\text { SE } \\
\text { Coef }\end{array}$ & $\mathrm{T}$ & $\rho$ & VIF \\
\hline Constant & 1.4062 & 0.2429 & 5.79 & 0.000 & \\
\hline $\mathrm{X}_{2}$ & 0.2832 & 0.1086 & 2.61 & 0.010 & 4.872 \\
\hline $\mathrm{X}_{4}$ & 0.3763 & 0.1105 & 3.41 & 0.001 & 4.389 \\
\hline $\mathrm{X}_{5}$ & $1.8 * 10^{-7}$ & $6 * 10^{-7}$ & 3.17 & 0.002 & 1.503 \\
\hline
\end{tabular}

$\overline{\text { Sedangkan hasil uji analisa varians disajikan dalam Tabel } 4 .}$

Tabel 4. Analisa Varians (ANOVA)

\begin{tabular}{llllll}
\hline Source & DF & SS & MS & F & $\rho$ \\
\hline Regression & 3 & 139.421 & 46.474 & 75.26 & 0.000 \\
Residual & 130 & 80.281 & 0,618 & & \\
$\begin{array}{l}\text { Error } \\
\text { Total }\end{array}$ & 133 & 219.701 & & & \\
\hline
\end{tabular}

Dari hasil analisa juga diperoleh nilai Durbin-Watson statistic $(\mathrm{D})=1.79360$. Nilai ini nantinya akan digunakan untuk mengetahui ada tidaknya autokorelasi dari persamaan regresi yang dihasilkan. Sedangkan nilai statistik deskriptif dari masing-masing variabel dapat dilihat pada Tabel 5

Tabel 5. Statistik Deskriptif

\begin{tabular}{cccccc}
\hline & \multicolumn{5}{c}{ SE } \\
Variabel & $\mathrm{N}$ & Mean & Mean & StDev & Median \\
\hline Y & 135 & 3.822 & 0.110 & 1.281 & 4 \\
X2 & 135 & 3.622 & 0.119 & 1.387 & 4 \\
X4 & 134 & 1.881 & 0.112 & 1.292 & 2 \\
X5 & 135 & 2.91 & 129238 & 1501605 & 3500000 \\
\hline
\end{tabular}

\subsection{Uji Normalitas}

Untuk menguji normalitas dari data yang digunakan dilihat dari tampilan histogram dan grafik probabilitas normal dari data yang diuji. Uji ini dimaksudkan untuk menentukan apakah sebaran data yang ada berdistribusi normal atau tidak juga apakah data yang diperoleh berasal dari populasi yang sama.

Salah satu ukuran yang dipakai adalah menggunakan grafik histogram dimana normalitas ditandai dengan grafik yang menyerupai bel lonceng ke atas yang dihasilkan dari residual yaitu selisih antara variabel dependen atau $\mathrm{Y}$ dengan $Y$ prediksi. Yang dimaksud dengan $Y$ prediksi adalah nilai Y berdasarkan hasil persamaan regresi. Gambar 2 menunjukkan residual berdistribusi normal oleh karena histogram menyerupai bel menghadap ke atas.

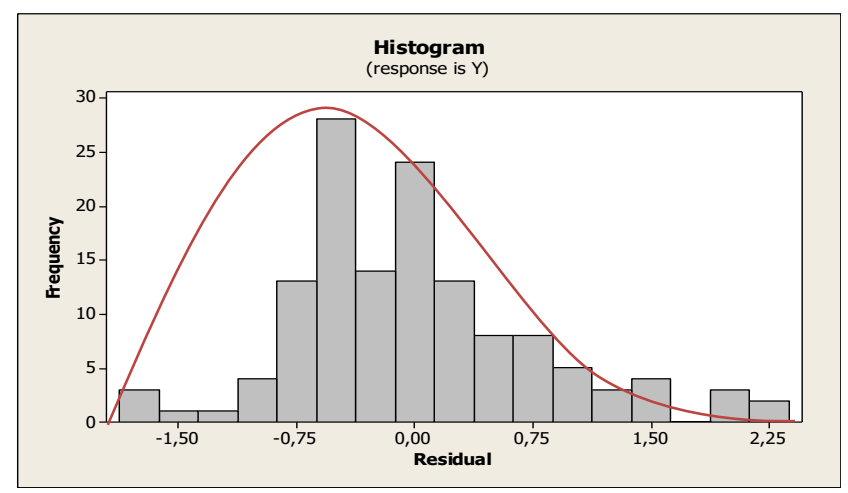

Gambar 2. Histogram

Sedangkan dari grafik Normal Probability Plot pada Gambar 3 terlihat bahwa residual berdistribusi pada garis lurus sehingga disimpulkan residual berdistribusi normal.

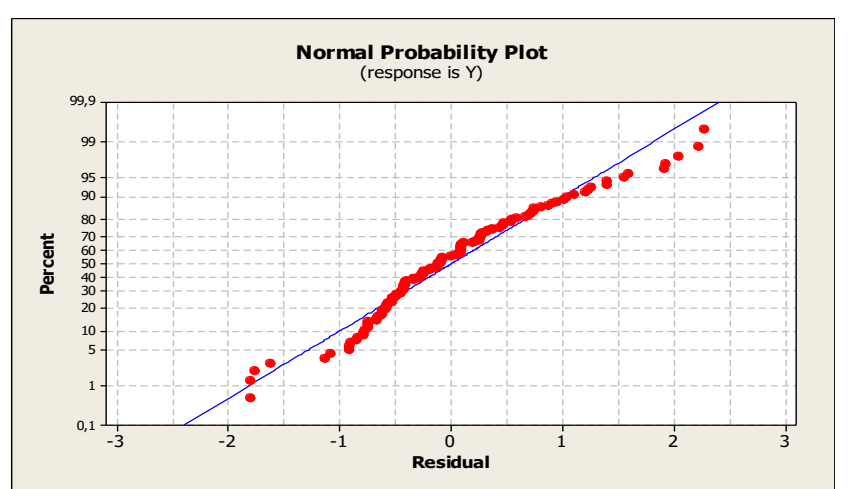

Gambar 3. Normal Probability Plot

\subsection{Uji Heteroskedastisitas}

Gejala heteroskedastisitas dapat ditentukan dengan diagram scatter antara variabel Y prediksi (Fits) dengan variabel residual.

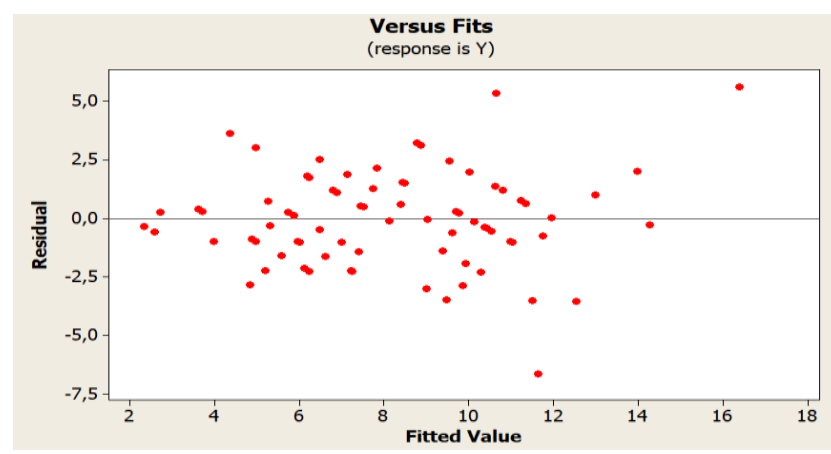

Gambar 4. Pola sebaran Versus Fits

Dari Gambar 3 di atas dapat terlihat bahwa plot residual menyebar merata di atas dan di bawah sumbu 0 tanpa membentuk sebuah pola tertentu. Diagram di atas dapat menyimpulkan bahwa tidak terdapat gejala heteroskedastisitas.

\subsection{Uji Multikolinearitas dan Autokorelasi}

Untuk mendeteksi adanya gejala multikolinearitas dapat dilihat dari nilai VIF. Dikatakan tidak ada gejala 
multikolinearitas apabila VIF < 5. Dari output hasil uji data nilai VIF 4.872, 4.389 dan 1.503 (Tabel 3) dimana kurang dari 5 maka dapat disimpulkan bahwa tidak ada gejala multikolinearitas.

Untuk mendeteksi adanya gejala autokorelasi positif dan negatif didasarkan pada nilai Durbin-Watson statistics (D). Pada output analisis di atas nilai D sebesar 1.79360 . Sedangkan dari tabel Durbin-Watson diperoleh $\mathrm{dL}=$ 1.68894 dan $\mathrm{dU}=1.7492$. Persyaratan tidak ada autokorelasi positif jika $\mathrm{D}>\mathrm{dL}$ dan $\mathrm{D}>\mathrm{du}$ sedangkan jika maka tolak $\mathrm{H}_{0} ; \mathrm{d}<\mathrm{d}_{\mathrm{U}}$ terima $\mathrm{H}_{0}$; dan jika $\mathrm{dL}=\mathrm{d}=\mathrm{du}$, pengujian tidak menyakinkan. Dari hasil uji Durbin-Watson diperoleh $\mathrm{D}=1.7936>\mathrm{dL}=1.68894$ dan $\mathrm{D}>\mathrm{dU}=$ 1.7492. Dengan demikian dapat disimpulkan tidak ada gejala autokorelasi positif.

Selanjutnya jika $4-\mathrm{D}>\mathrm{dL}$ dan $4-\mathrm{D}>\mathrm{dU}$ maka tidak terdapat autokorelasi negatif serta jika $d_{L}<(4-D)<d U$ maka pengujian tidak meyakinkan. Dari nilai DurbinWatson $\mathrm{D}=1.79360$ maka $4-\mathrm{D}=2.2064>\mathrm{dL}=1.68894$ dan $4-\mathrm{D}>\mathrm{dU}=1.7492$. Dengan demikian dapat pastikan bahwa tidak ada gejala autokorelasi negatif dan pengujian adalah meyakinkan serta dapat diambil kesimpulan.

\subsection{Uji F Regresi dan T Parsial}

Untuk memastikan bahwa semua variabel independen yang dimasukkan dalam analisis regresi secara bersama-sama berpengaruh pada variabel terikat maka dilakukan uji $\mathrm{F}$ pada regresi. Uji ini merupakan pengujian yang sifatnya sebagai uji simultan dan tingkat pengaruh ditunjukkan dari nilai $\rho$ value $<0.05$ pada tingkat kepercayaan $95 \%$. Disimpulkan ada pengaruh apabila nilai $\rho$ value kurang dari batas kritis penelitian atau alpha. Pada uji ini, nilai $\rho$ regression pada Analysis of Variance (Anova) sebesar 0,000 di mana < 0.05 (tabel 4) maka disimpulkan bahwa secara simultan variabel independen $\left(\mathrm{X}_{2}, \mathrm{X}_{4}, \mathrm{X}_{5}\right)$ mempunyai pengaruh bermakna terhadap variabel dependen (Y).

Uji lainnya adalah uji T parsial yang dimaksudkan untuk melihat sejauh mana pengaruh masing-masing variabel bebas dalam model regresi terhadap variabel terikat dan tetap memperhatikan variabel lain dalam model. Nilai hasil pengujian ini ( $\mathrm{T}$ parsial) dapat dilihat melalui nilai $\mathrm{T}$ pada hasil analisis (Tabel 3). Ketentuannya adalah variabel dinyatakan berpengaruh secara parsial jika nilai $\rho$ value kurang dari batas kesalahan $\alpha=0.05$. Dari hasil analisis pada Tabel 3, diketahui bahwa semua variabel independen memiliki nilai $\rho$ value $\mathrm{T}$ parsial $<0.05$ maka semua variabel bebas berpengaruh secara individu terhadap $\mathrm{Y}$ dengan memperhatikan variabel lain.

\subsection{Persamaan Regresi}

Persamaan regresi dalam analisis ini kemudian dibentuk dari nilai koefisien $\beta$ pada output hasil analisis pada Tabel 3. Secara berurutan dari atas ke bawah:
a) Constant: 1.4062
b) $\beta_{2}: 0.2832$
c) $\beta_{4}: 0.3763$
d) $\beta_{5} \quad: 1.8 * 10^{-7}$

Dengan demikian persamaan regresi dapat ditulis sebagai berikut :

$$
Y=1.4062+0.2832 X_{2}+0.3763 X_{4}+1,8 * 10^{-7} X_{5}
$$

Dari persamaan regresi di atas dapat nyatakan beberapa hal sebagai berikut:

1. Apabila variabel lain bernilai konstan, Nilai Y akan berubah dengan sendirinya sebesar nilai konstanta yaitu 1.4062 atau dapat dikatakan pula jika variabel lain tidak ada maka bangkitan perjalanan akan terjadi sebesar 1.4062 kali per hari.

2. Apabila variabel lain bernilai konstan maka setiap penambahan 1 anggota keluarga akan menyebabkan terjadinya bangkitan sebesar 0,2832 setiap satu satuan $\mathrm{X}_{2}$.

3. Apabila variabel lain bernilai konstan maka setiap penambahan 1 orang anggota keluarga yang bersekolah maka akan menyebabkan bangkitan sebesar 0.3763 setiap satu satuan X4.

4. Apabila variabel lain bernilai konstan maka penambahan 1 satuan penghasilan keluarga maka akan menyebabkan bangkitan perjalanan sebesar $1.8 * 10^{-7}$ setiap satu satuan X5.

Selanjutnya, untuk menilai kekuatan model dalam melakukan peramalan perjalanan ini maka nilai R Square dapat dijadikan sebagai rujukan. Nilai ini sering disebut juga sebagai koefisien determinasi berganda. Dari hasil analisa yang termuat dalam Tabel 3 diketahui bahwa R-Sq sebesar $63.5 \%$ yang artinya adalah variabel bangkitan perjalanan (Y) dapat dijelaskan oleh sekelompok variabel independen Jumlah anggota keluarga $\left(\mathrm{X}_{2}\right)$, jumlah anggota keluarga yang bersekolah $\left(\mathrm{X}_{4}\right)$ dan penghasilan keluarga $\left(X_{5}\right)$ secara serentak atau simultan sebesar $63.5 \%$ sedangkan sisanya $(100 \%-63.5 \%=36.5 \%)$ dijelaskan oleh variabel lain di luar model yang tidak diteliti.

Selain itu, model persamaan regresi juga sering disebut sebagai model prediksi oleh karena adanya variabel terikat dan variabel bebas. Untuk menguji validitas model sebagai model prediksi maka dapat dilihat dari nilai Standart Error of Estimate (SEE) yaitu sebesar $\mathrm{S}=0.785840 \quad$ (Tabel 3). Nilai SEE ini bandingkan dengan deviasi standar dari variabel dependen atau $\mathrm{Y}=1.281$ (Tabel 5) sehingga diperoleh SEE $=0.785840<$ StDev $\mathrm{Y}=1.281)$, maka dapat dinyatakan model regresi di atas adalah valid sebagai model prediksi. 


\subsection{Diskusi}

Telah dijelaskan di atas bahwa variabel yang berpengaruh terhadap bangkitan perjalanan pada kawasan pinggiran kota di Kupang adalah jumlah anggota keluarga, jumlah anggota keluarga yang sekolah dan penghasilan keluarga. Temuan ini sejalan dengan studi yang dilakukan oleh Pidor, Karels dan Bolla [15], yang melakukan studi sebelumnya di dalam kota Kupang bahwa salah satu faktor yang berpengaruh pada bangkitan perjalanan adalah jumlah anggota keluarga yang sekolah.

Sementara studi lainnya juga menunjukkan hasil yang konsisten bahwa variabel yang berpengaruh dalam bangkitan perjalanan adalah variabel jumlah anggota keluarga dan pendapat per bulan dari rumah tangga di samping variabel lainnya yaitu kepemilikan kendaraan dan ukuran rumah tangga [16].

Hasil ini juga menunjukkan bahwa perjalanan yang dilakukan anak sekolah signifikan berpengaruh pada bangkitan perjalanan menuju kawasan perkotaan. Oleh karena itu, pemerintah perlu memberikan akses yang baik dalam mendapatkan layanan pendidikan yang dekat dengan kawasan pinggiran kota, sehingga dapat mengurangi perjalanan ke kawasan perkotaan untuk bersekolah.

\section{DAFTAR PUSTAKA}

[1] Puji Hardati, "Transformasi wilayah peri urban. kasus di Kabupaten Semarang," Jurnal Geografi, vol. 8, no. 2, pp. 108-177, Juli 2011.

[2] Nanda Adi Prawatya, "Perkembangan spasial kotakota kecil di Jawa Tengah," Jurnal Wilayah dan Lingkungan, vol. 1, no. 1, pp. 17-31, April 2013.

[3] La Ode Muhamad Magribi and Aj. Suhardjo, "Aksesibilitas dan pengaruhnya terhadap pembangunan pedesaan; Konsep Model Sutainable Accselibility pada kawasan pedesaan di Propinsi Sulawesi Tenggara," Jurnal Transportasi, vol. 4, no. 2, pp. 149-160, Desember 2004.

[4] Juan de Dios Ortúzar and Luis G Willumsen, Modelling Transport.: Wlley, 2001.

[5] Michael G MacNally, "Four Step Model," in Hand Book of Transport Modeling., 2016, pp. 35-33.

[6] Ofyar Z Tamin, Perencanaan, Pemodelan \& Rekayasa Transportasi: Teori, contoh soal dan Aplikasi. Bandung: ITB, 2008.

[7] Abhishek L Hedau and S S Sanghai, "Development of Generation Model Using Activity Based," International Journal of Civil, Structural, Environmental and Infrastructure Engineering Research and Development (IJCSEIERD), vol. 4, no. 3, pp. 61-78, Jun 2014.

\section{KESIMPULAN}

Berdasarkan hasil yang diperoleh dari penelitian ini dan dari beberapa studi terdahulu, menegaskan bahwa faktor yang terlihat berpengaruh paling dominan dalam melakukan perjalanan adalah faktor rumah tangga seperti jumlah anggota keluarga, pendapatan dan juga kepemilikan kendaraan. Motivasi umumnya untuk melakukan perjalanan adalah untuk tujuan bersekolah dan bekerja. Dengan demikian kebutuhan akan perjalanan akan sangat bergantung pada faktor rumah tangga. Oleh karena itu, dalam merencanakan sistem transportasi perkotaan perlu untuk melakukan kajian terhadap aspek ini secara lebih mendalam dan komprehensif. Studi selanjutnya disarankan untuk melakukan telaah terhadap dampak timbal balik antara kebutuhan perjalanan dengan pertumbuhan dan perkembangan kawasan pinggiran kota serta dampaknya terhadap kawasan pusat kota.

\section{UCAPAN TERIMA KASIH}

Artikel ini merupakan bagian dari Penelitian Dosen Pemula (PDP). Untuk itu kami mengucapkan terima kasih yang sebesar-besarnya kepada Direktorat Jenderal Penguatan Riset dan Pengembangan Kementerian Riset, Teknologi dan Pendidikan Tinggi yang mendanai penelitian ini dan LPPM Politeknik Negeri Kupang atas kerja samanya selama ini.

[8] William Davidson et al., "Synthesis of first practices and operational research approaches in activity-based travel demand modeling," Transportation Research Part A, vol. 41, pp. 464-488, 2007.

[9] Eric J Miller, James Vaughan, David King, and Matthew Austin, "Implementation of a "Next Generation" Activity-Based Travel Demand Model: The Toronto Case," in Paper prepared for presentation at the Travel Demand Modelling and Traffic Simulation Session of the 2015 Conference of the Transportation Association of Canada, Charlottetown, 2015, pp. 1-20.

[10] Sonya Sulistyono and Wiwik Yunarni Widiarti, "Pemodelan bangkitan perjalanan (Trip Generation) pada kawasan pusat Kota Jember," in Simposium $X$ FSTPT, Universitas Tarumanagara, Jakarta, 2007, pp. $1-9$.

[11] Jurair Patunrangi, "Model bangkitan pergerakan zona kecamatan palu utara Kota Palu," Jurnal SMARTek, vol. 8, no. 3, pp. 191-202, Agustus 2010.

[12] Adris A. Putra, "Model Bangkitan Pergerakan Penduduk pada kawasan pemukiman," TEKNO SIPIL , vol. 11, no. 58, pp. 19-26, April 2013.

[13] Luis A. Guzman, Ana M. Gomeza, and Carlos Riveraa, "A Strategic Tour Generation Modeling within a Dynamic Land-Use and Transport Framework: A Case Study of Bogota, Colombia," in World Conference on Transport Research Transportation Research Procedia 25C, Shanghai, 
2017, pp. 2540-2555.

[14] Sugiyono, Statistik untuk Penelitian, X ed., Endang Mulyatiningsih, Ed. Bandung: CV. Alfabeta, 2006.

[15] Maria S. Pidor, Dolly W. Karels, and Margareth E. Bolla, "Bangkitan perjalanan dan pola pergerakan penduduk Kecamatan Kepala Lima," Jurnal Teknik Sipil, vol. VII, no. 2, pp. 119-132, September 2018.

[16] Michael Octavianus and Indra Jaya Pandia, "Bangkitan perjalanan pada perumahan Menteng Indah di Kecamatan Medan Denai," Jurnal Teknik Sipil USU, vol. 2, no. 2, 2013. 